\title{
Fungal keratitis in a mare: case report in Costa Rica
}

\section{Queratitis fúngica en una yegua: reporte de un caso en Costa Rica}

\section{Ceratite fúngica em égua: relato de um caso na Costa Rica}

\author{
Eugenia Bermúdez-Jiménez ${ }^{1 凶}$ Alejandra Calderón-Hernández $z^{2,3}$ \\ 1 EyeVet Costa Rica, Santa Ana, San José, Costa Rica. ginibj@gmail.com \\ 2 Laboratorio Diagnóstico Albéitar S.A., Pavas, San José, Costa Rica. \\ 3 Laboratorio de Micología, Escuela de Medicina Veterinaria, Universidad Nacional, Heredia, Costa Rica. \\ alejandra.calderon.hernandez@una.cr
}

Received: August 12, 2020 Corrected: October 29, 2020 Accepted: October 30, 2020

\begin{abstract}
This paper discusses the diagnosis and clinical management of a case of equine keratomycosis. A pregnant Iberic mare was diagnosed with Aspergillus subgenus Circumdati section Circumdati, by direct microscopic examination, cytology, and fungal culture after being treated with a topical antibiotic and steroid drops in her left eye for over a month. The mare developed a melting ulcer and, as a result, topical miconazole $1 \%$ was prescribed; while being treated the iris prolapsed, and surgery was suggested but not conducted. After the treatment, the eye was not visual but in the orbit.
\end{abstract}

Keywords: Aspergillus, horse, iris prolapse, keratomycosis, melting ulcer, miconazole

\section{Resumen}

Se discute el manejo clínico y diagnóstico de un caso de queratomicosis en un equino. Una yegua Ibérica preñada fue diagnosticada con Aspergillus subgénero. Circumdati sección Circumdati mediante examen microscópico directo, citología y cultivo micológico, después de haber sido tratada por un mes con gotas de corticoesteroides y antibiótico tópico en su ojo izquierdo. Desarrolló úlcera colagenolítica, se prescribió tratamiento con miconazol tópico al $1 \%$ y posteriormente presentó prolapso de iris, la cirugía fue sugerida pero no fue realizada. Al final del tratamiento médico, el ojo no es visual, pero está en órbita.

Palabras clave: Aspergillus, caballo, prolapso de iris, queratomicosis, úlcera colagenolítica, miconazol

\section{Resumo}

Discute-se o manejo clínico e diagnóstico de um caso de ceratomicose em um equino. Uma égua ibérica prenha foi diagnosticada com Aspergillus subgen. Circumdati seção Circumdati por exame microscópico direto, citologia e cultura micológica, após ter sido tratada por um mês com colírio de corticosteróides e antibiótico tópico no olho esquerdo. Desenvolveu úlcera colagenolítica, foi prescrito tratamento com miconazol tópico a $1 \%$ e posteriormente apresentou prolapso de íris, cirurgia foi sugerida, mas não realizada. No final do tratamento médico, o olho não é visual, mas está em órbita.

Palavras-chave: Aspergillus, cavalo, prolapso de íris, ceratomicose, úlcera colagenolítica, miconazol

Correo de correspondencia: ginibj@gmail.com 


\section{Introduction}

One of the most frequent reasons for an ophthalmic examination in the equine practice is corneal disease. The prominent equine eye contributes to a higher degree of exposure of the cornea (Barnett et al. 2004; Clode 2011). Corneal keratitis is frequent and can be ulcerative and non-ulcerative. Both infectious and non-infectious causes can be found in both categories (Clode 2011; Gilger 2013).

Trauma is a common trigger in ulcerative keratitis (Galera \& Brooks 2012; Gilger 2013). When the corneal epithelium is damaged, the epithelium takes about five to seven days to restore during a normal healing process (Maggs 2008; Clode 2011). When a nonhealing corneal ulcer is present, bacterial or fungal infections are easier to develop, making the ocular problem more challenging (Clode 2011).

Keratomycosis is a conjunctiva and cornea infection due to commensal fungi. The clinical signs associated with keratomycosis are stromal plaques and abscess, blepharospasm, micro erosions, corneal vascularization, pain, chemosis, photophobia, lacrimation, purulent discharge, miosis, keratomalacia, keratitis, hypopyon, uveitis, iris prolapse, and corneal edema (Galán et al. 2009; Brooks et al. 2013; Cafarchia et al. 2013). Considering that those clinical manifestations are shared with other etiologies, laboratory tests must be used for confirmation.

The aim of this case report is to advise equine veterinarians, mostly from developing countries such as Costa Rica, of the importance of using laboratory tests to provide better prognosis and improve animal welfare before resorting to empirical antifungal treatments.

\section{Case report}

On December 11 $1^{\text {th }}, 2013$ (day 1), a pregnant Iberic mare, semi-stabled from La Ceiba, Orotina, Alajuela, Costa Rica, was evaluated for chronic pain and epiphora on her left eye (Fig. 1). The patient had been treated for several weeks with topical antibiotic and steroid drops (Tobradex: $0.3 \%$ tobramycin and $0.1 \%$ dexamethasone, Alcon).

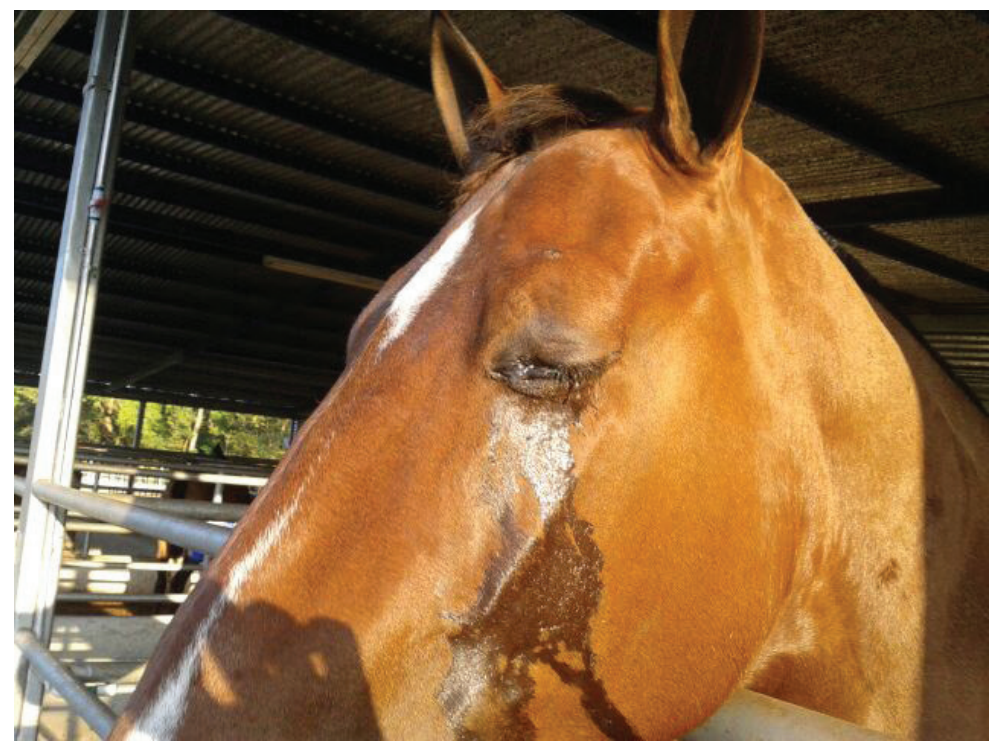

Figure 1. Epiphora and eyelids closed due to severe pain. 


\section{Ophthalmic evaluation}

On day one, an ophthalmic evaluation was conducted in the morning, using $0.5 \%$ tetracaine ophthalmic drops (Alcames, Costa Rica), direct ophthalmoscope (Welch Allyn, Skaneateles Falls, NY), PanOptic ophthalmoscope (Welch Allyn, Skaneateles Falls, NY), and Tono-pen applanation tonometry (Reichert, Inc, Depew, NY). The ophthalmic evaluation consisted of checking the anterior and posterior segments, light responses, intraocular pressure, and fluorescein sodium $1 \mathrm{mg}$ staining strip (Bio Glo, Hub Pharmaceuticals). The left eye (OS) presented abundant epiphora and blepharospasm, and the cornea had superficial erosion positive for fluorescein sodium staining strip (Fig. 2), miosis, and normal fundus. The right eye (OD) was normal. Intraocular pressure was normal in both eyes: OS $30 \mathrm{mmHg}$ and OD $32 \mathrm{mmHg}$ (range 7 - $37 \mathrm{~mm} \mathrm{Hg}$ ) (Utter \& Brooks 2011).
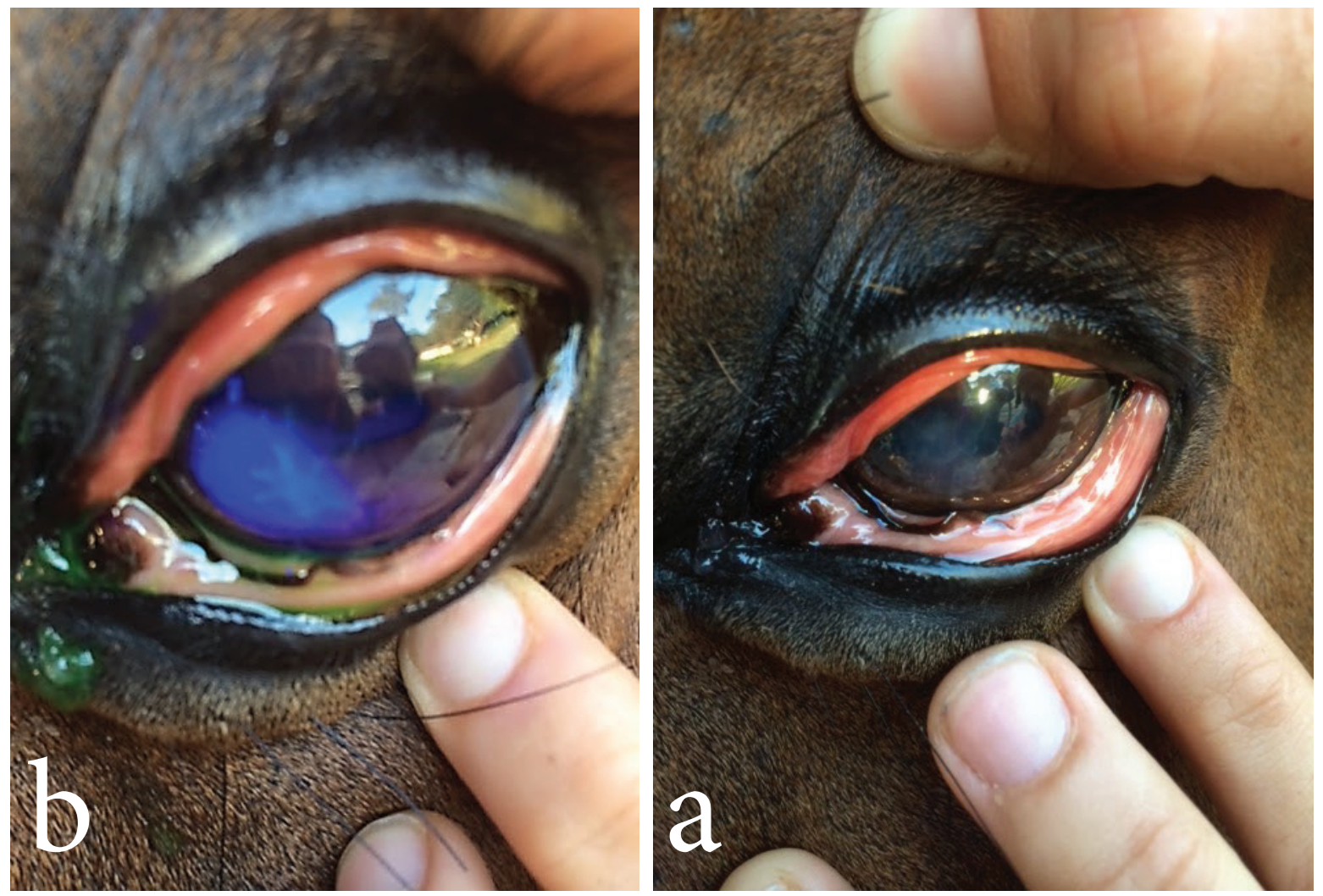

Figure 2. Ophthalmic evaluation of the left eye. a) loss of transparency of the corneal medial aspect, erosion noted with magnification. b) corneal medial aspect positive for fluorescein (corneal ulcer).

By day 3, the left eye presented less epiphora, the pupil was dilated, and the mare was able to open the eyelids wider (Fig. 3). 


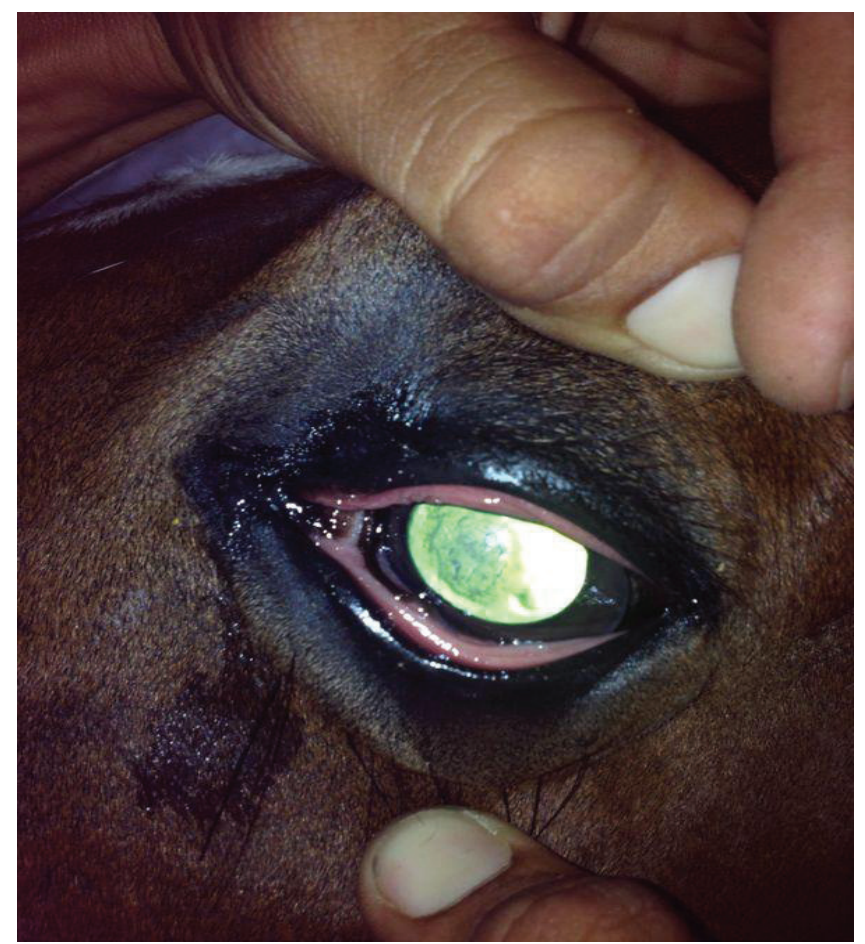

Figure 3. Mydriasis, tapetal reflex (green color), and cornea with furrowing appearance.

On day 6, the mare was able to close the eyelids again. On the cornea, blood vessels started advancing dorsally and the melting process initiated (Fig. 4).
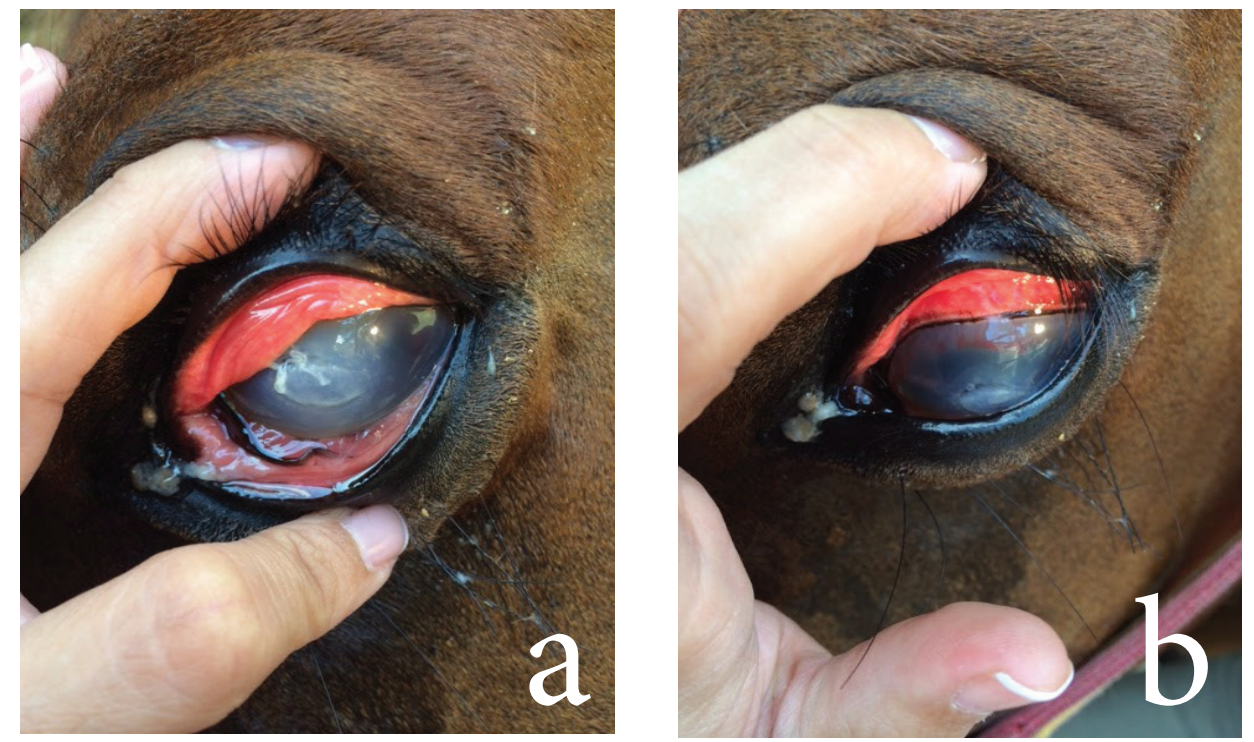

Figure 4. a) Corneal edema and beginning of the melting process b) Note the redness on the sclera and the blood vessels on the dorsal aspect of the cornea. 
By day 8, the melting process was severe (Fig. 5). Since clinical signs worsened and there was no response to antibiotics, corneal scraping and impression smear were immediately taken to the laboratory for fungal tests and cytology. In the following weeks, the cornea continued to get weaker until it ruptured.

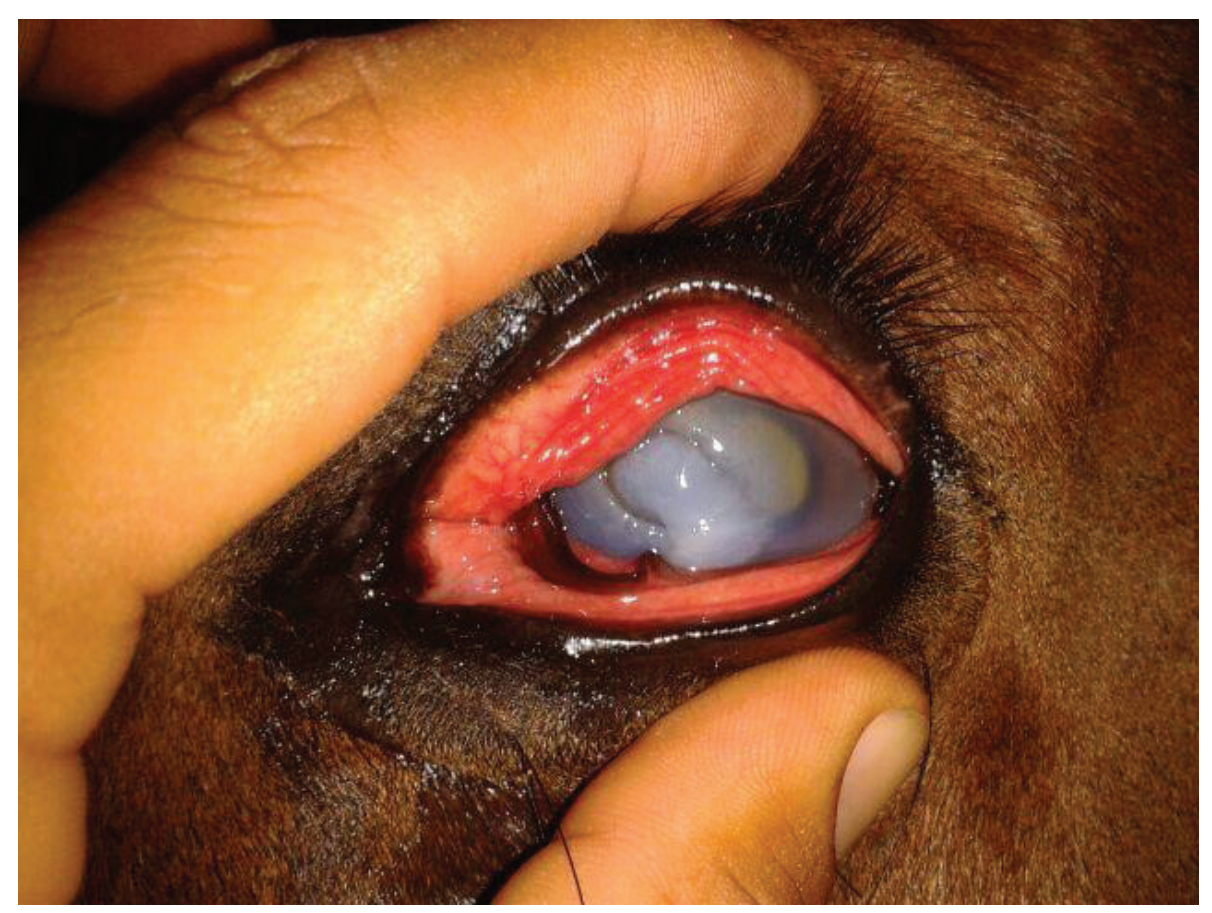

Figure 5. Generalized corneal edema. The tip of the melting tissue was used for laboratory tests.

\section{Cytology and mycology results}

Samples were processed and analyzed as soon as they arrived at the lab (Diagnóstico Albéitar, S.A.) less than two hours after they were taken. Wright's stain was used for the impression smear. The cytology revealed corneal epithelial cells with slight dysplasia and neutrophilic inflammation. A direct microscopic examination with $10 \%$ potassium hydroxide $(\mathrm{KOH})$ made to the corneal scraping showed abundant hyaline septate hyphae of 3-4 $\mu \mathrm{m}$ in diameter, some of which showed dichotomous branching at $45^{\circ}$ (Fig. 6). Consequently, a hyaline fungal keratitis was diagnosed (Walsh et al. 2018; de Hoog et al. 2019). 

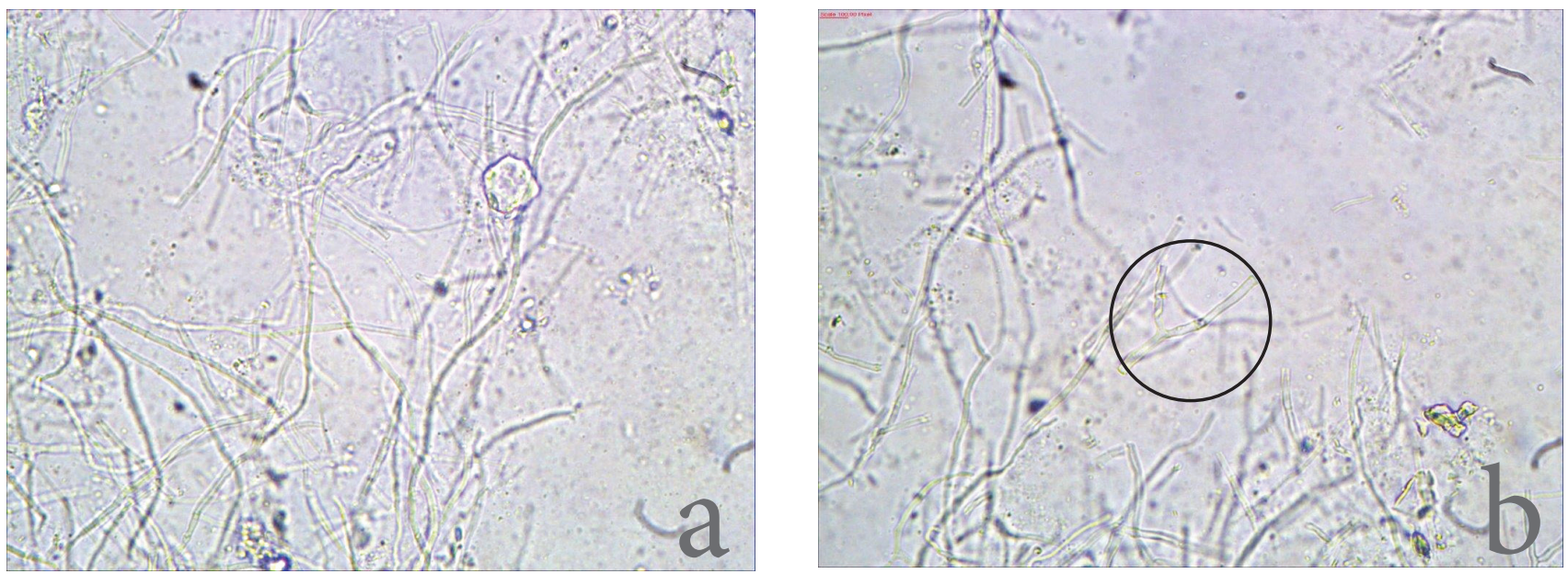

Figure 6. Microscopic direct examination of corneal scraping with $\mathrm{KOH} \mathrm{10 \% ,400x.} \mathrm{a.} \mathrm{Abundant} \mathrm{hyaline} \mathrm{septate} \mathrm{hyphae.}$ b. Delimited by a circle, hyphae with dichotomous branching at $45^{\circ}$.

Cultures in Sabouraud Dextrose Agar (Oxoid ${ }^{\circledR}$, Basingstoke, United Kingdom) at $37{ }^{\circ} \mathrm{C}$ and $28^{\circ} \mathrm{C}$ for seven days yielded positive for a hyaline powdery colony with yellowish conidia, and no sexual stages were present (Walsh et al. 2018; de Hoog et al. 2019; Samson et al. 2019) (Fig. 7).

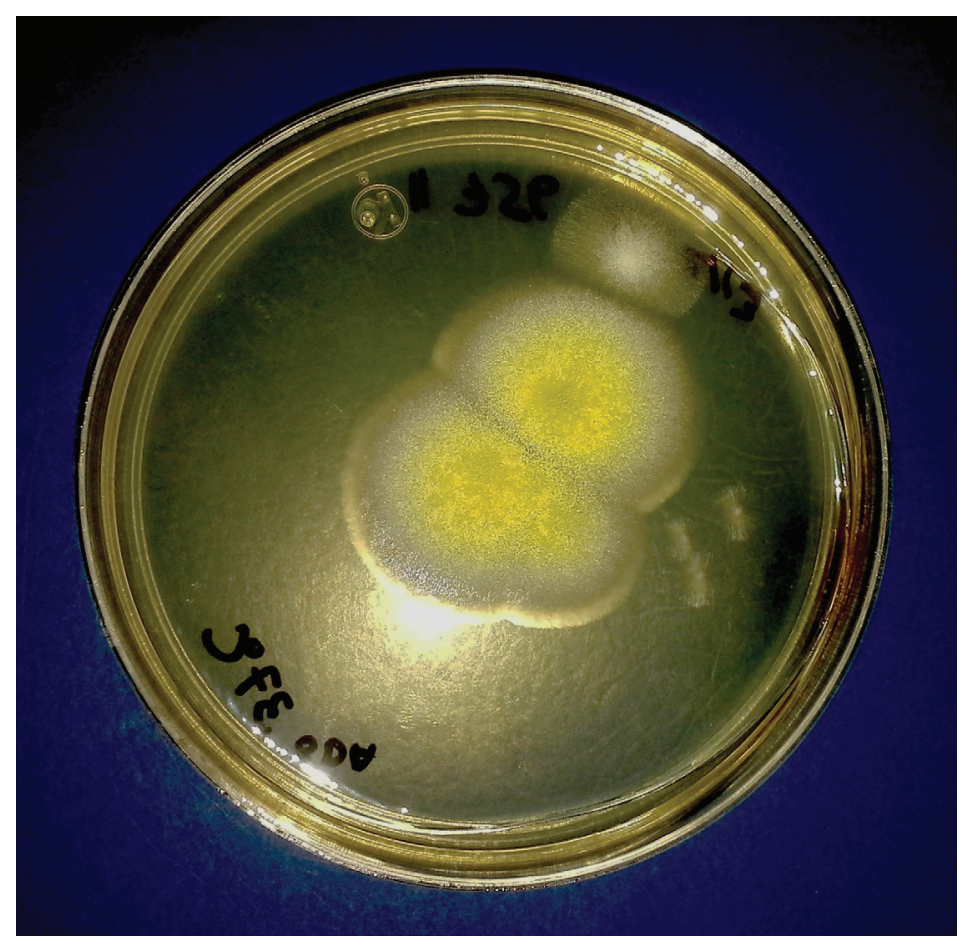

Figure 7. Seven-day culture of corneal scraping positive for Aspergillus subgenus Circumdati section Circumdati on SDA at $37^{\circ} \mathrm{C}$. 
The micromorphology analyzed at the Mycology Lab of the School of Veterinary Medicine at Universidad Nacional de Costa Rica (LMIC EMV-UNA) showed a hyaline septate hypha of 3-4 $\mu \mathrm{m}$ in diameter, with erect and unbranched conidiophores and the phialides disposition in the vesicle radiated and biseriate (Fig. 8). Since no molecular methods were accessible at that time in the country, it was identified as Aspergillus spp. to genera level. Although the strain is no longer available, it was later identified to section level as an Aspergillus subgenus Circumdati section Circumdati based on the color of the conidia and the disposition of the phialide in the vesicle (Walsh et al. 2018; de Hoog et al. 2019; Samson et al. 2019; Houbraken et al. 2020).

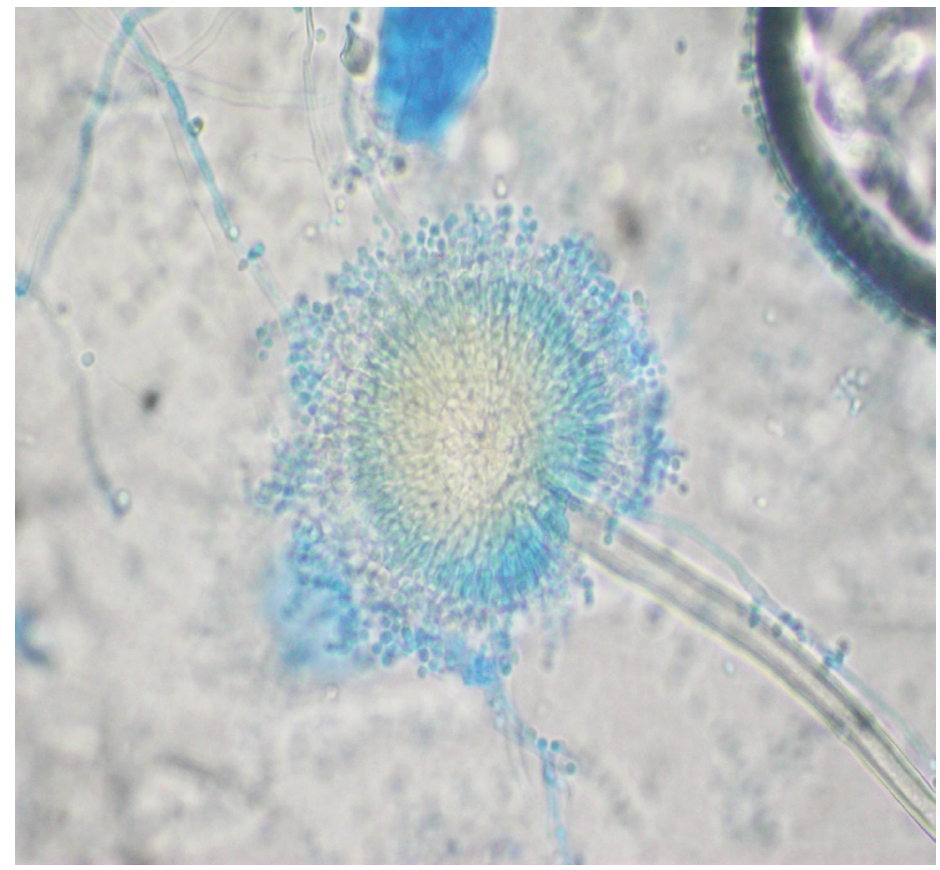

Figure 8. Aspergillus subgenus Circumdati section Circumdati radiate conidial head. Lactophenol Cotton Blue Solution, 400x.

\section{Treatment and follow up}

On the day of the ophthalmic evaluation, the mare started with topical tobramycin (Tobrex: $0.3 \%$ tobramycin, Alcon), diclofenac (3a Ofteno: 0.1\% diclofenac, Sophia), atropine (Atropina: 1\% atropine, Holliday), and oral phenylbutazone (Fenilbutazona: $1 \mathrm{~g}$ phenylbutazone, Lisan, no longer available). By day 6, when the melting process started, topical autologous serum, EDTA (Ethylenediaminetetraacetic acid), and ofloxacin (Ofloxacina: ofloxacin $0.3 \%$, Holliday) were added to the treatment.

With the presence of hyaline septate hyphae, a $1 \%$ miconazole solution was added to the therapy by day 9 , and a conjunctival pedicle graft surgery was recommended to help prevent corneal perforation. As per the owner's decision, the mare continued only with medical treatment. 
The mare was under treatment for almost two months. Although the cornea suffered a perforation with iris prolapse, it eventually healed. To date, the patient's left eye is not visual, but it is in the orbit (Fig. 9).
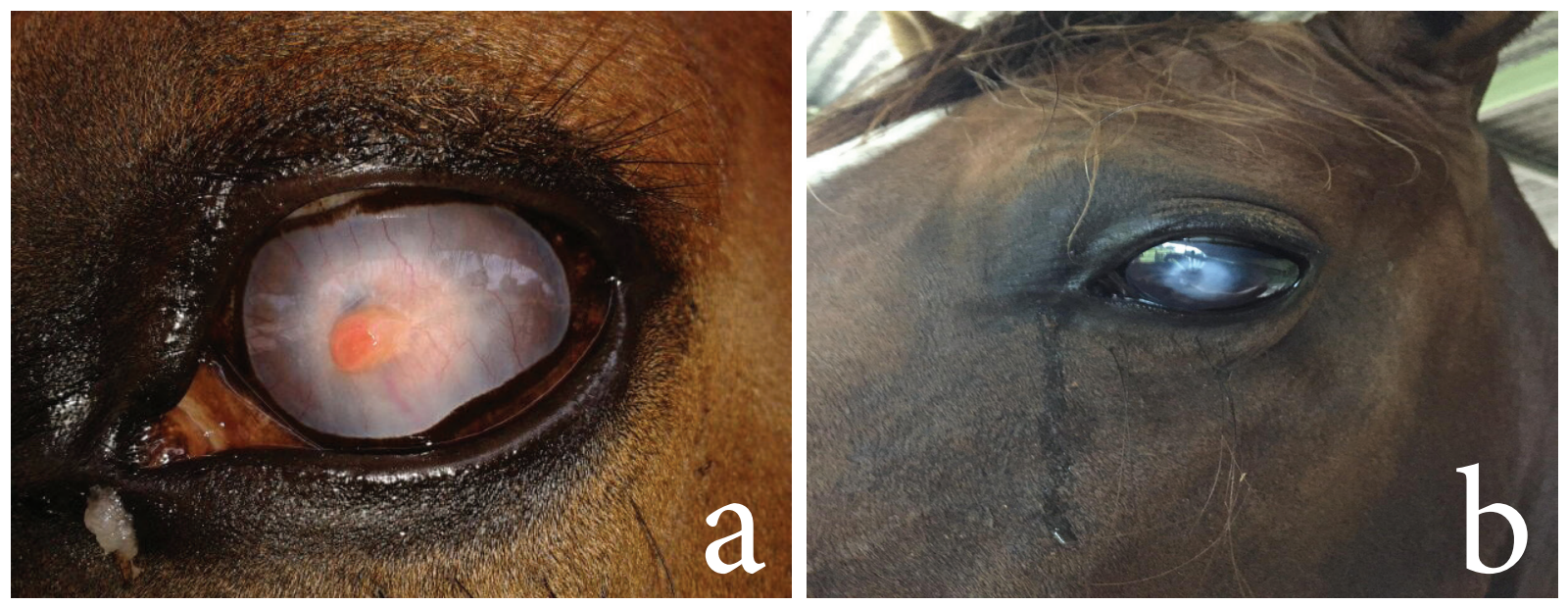

Figure 9. a) blood vessels and ongoing healing process b) scar tissue of the cornea

\section{Discussion}

Horses are more likely predisposed to mycotic infections in their eyes than are other mammals because of deficiencies in the innate immune protective barriers of the tear film to develop an adequate response against fungi present in the conjunctiva and the cornea, also because of a lack of integrity and stability of the precorneal tear film, a large corneal surface, and low resting temperature of the cornea (Galán et al. 2009; Galera \& Brooks 2012; Cafarchia et al. 2013; Khosravi et al. 2014). Fungal eye infections can be found in the cornea, eyelids, conjunctiva, orbit, and intraocular and can affect the optic nerve as a consequence of trauma due to opportunistic overgrowth or a systemic disseminated disease (Ledbetter 2017). In these cases, the diagnosis should include an exhaustive ophthalmic evaluation and laboratory tests to prescribe the correct treatment.

In normal conditions, the ocular microbiota, mostly made of Gram-positive bacteria, yeast, and filamentous fungi and at a lesser degree of Gram-negative bacilli, remains stable on the eye surface and conjunctiva to prevent pathogen overgrowth. The microbiota related to keratomycosis varies according to geographical areas, seasons, and housing conditions (Galera \& Brooks 2012; Khosravi et al. 2014). For example, Wada et al. (2011) found Mortierella wolfii in a 2-year-old Thoroughbred filly in Japan, and no cases involving this fungus had been described causing keratitis anywhere else. This fungus is a prevalent cause of abortion and meningoencephalitis in cattle in New Zealand, Australia, Japan, and England. The authors stated that the possible source could be environmental spores in the silage.

Although bacterial infections in the cornea are treated more frequently than fungal infections, living in tropical weather may increase the probability of developing keratomycosis (Maggs 2008; Gilger 2013; Utter 2015). However, the incidence of fungal keratitis in Costa Rica is either very low or well under-diagnosed since, to our knowledge, this is the first case reported in the country, as reflected in 
the keratomycosis cases recorded in LMIC EMV-UNA between 2008 to 2017 (Calderón-Hernández \& Urbina-Villalobos 2018). This condition also seems to be sporadic in other countries. After reviewing one-year to twelve-year retrospective studies in the United Kingdom, Spain, the United States, Switzerland, and Japan, the reported cases varied from five to 66 horses (Sansom et al. 2005; Galán et al. 2009; Utter et al. 2010; Brooks et al. 2013; Voelter-Ratson et al. 2013; Wada et al. 2013; Sherman et al. 2017). The research by Utter et al. (2010) in the mid-Atlantic United States deserves attention due to the large number of registered cases ( 30 in one year), although these horses were evaluated by a single board-certified veterinary ophthalmologist in comparison to the other papers where subjects were evaluated at Veterinary Teaching Hospitals. It could be deduced that environmental conditions, mostly during the summer in that geographical area, lead to more cases than in any other parts of the world. The studies with the most registered cases (Utter et al. 2010 with 30 and Sherman et al. 2017 with 66) revealed that the disease is present in ages ranging from one month to 30 years, with no sex predisposition, with eight breeds being represented for the former study and 14 for the latter, with Quarter Horse and Thoroughbred being the most affected ones (20-22\% and 20-30\% of the cases). In addition, both eyes were equally affected, always in a unilateral presentation. As far as use, both studies indicate horses were frequently exposed to the environment (mainly racing and sports) (Utter et al. 2010; Sherman et al. 2017).

Several fungal genera are associated with keratomycosis, including Aspergillus, Fusarium, Candida, Curvularia, Penicillium, Cylindrocarpon, and Mucor (Galán et al. 2009; Utter et al. 2010; Galera \& Brooks 2012; Wada et al. 2013; Samanta 2015; Sherman et al. 2017; Ledbetter et al. 2018), the first two being the most frequently reported and with the worst prognosis (Galán et al. 2009; Utter et al. 2010; Cafarchia et al. 2013; Sherman et al. 2017; Roberts et al. 2020). Since these genera are also found in healthy eyes (Khosravi et al. 2014), a fungal culture must be conducted with histopathology and/or cytology to verify whether the tissue has been compromised with hyphae or yeast. Fungal commensal overgrowth could result from high amounts of conidia in stables, mainly during summer and autumn in temperate countries and throughout the year in tropical areas (Galera \& Brooks 2012; Cafarchia et al. 2013).

It has been reported and assumed that fungal organisms have a tropism for the glycosaminoglycans in the equine deep corneal stroma close to Descemet's membrane (Utter 2015; Ledbetter et al. 2018). In addition, in a study using in vivo confocal microscopy, Ledbetter et al. (2018) were able to evidence the presence of fungal organisms even when the epithelium is still present, which suggests a similar tropism for the corneal epithelial basement membrane.

When a superficial epithelial lesion exists, the release of proteolytic enzymes from fungi, leukocytes, and keratocytes results in the progression of keratomycosis to deeper layers of the cornea, threatening vision (Wada et al. 2013; Ledbetter et al. 2018). The use of topical antimicrobials and topical corticosteroids can impair the local immune defenses, and opportunistic pathogens such as fungi can proliferate easily. In addition, collagenolysis can be devastating (Utter 2015).

Different clinical manifestations of keratomycosis include stromal ulcers, superficial fungal keratitis, keratomycosis with surrounding furrows, keratomycosis with a "cake frosting" appearance, and stromal abscesses (Sansom et al. 2005). Given that some can exhibit characteristics similar to bacterial infections and that the patient is already on antibiotic therapy, a cornea with a "cake frosting" or 
Rev. Ciencias Veterinarias, Vol. 38, N² 2, [30-42], E-ISSN: 2215-4507, julio-diciembre, 2020

DOI: https://doi.org/10.15359/rcv.38-2.3

URL: http://www.revistas.una.ac.cr/index.php/veterinaria/index

Ciencias

Veterinarias

furrowing appearance (like the present case) must be considered a sign to suspect the presence of fungi organisms to be confirmed with a fungal culture (Sansom et al. 2005).

Differential diagnoses include eosinophilic keratoconjunctivitis and keratoconjunctivitis sicca, immunemediated keratitis, bacterial keratitis, herpes virus keratitis, calcific band and traumatic keratopathy, corneal degeneration, and neoplasia (Galera \& Brooks 2012). Regarding the case in question, bacterial, eosinophilic, and neoplastic etiologies were discarded after cytology.

Some of the diagnostic tests used to determine a fungal etiology include culture, cytology, histopathology, polymerase chain reaction, and in vivo laser scanning confocal microscopy (Galera \& Brooks 2012; Ledbetter et al. 2018), all of which, except for the last one, are currently available in Costa Rica at affordable prices. However, depending on the lesion's progression and the availability of the specimen collection, taking the samples and choosing the tests could be a challenge (Ledbetter et al. 2018). For example, in a five-year retrospective study using medical records of twenty-one horses with subepithelial keratomycosis, only ten cases of mycotic etiology were cytologically confirmed and only four cases were positive for fungal isolates: Candida spp. in one of the cases and Aspergillus spp. in three (Brooks et al. 2013).

In the present case, Aspergillus subgenus Circumdati section Circumdati was identified as the causative agent. Since this genus can be found as transitory microbiota (Khosravi et al. 2014), the etiology was confirmed by culture, the visualization of the parasitic adaptation on the direct microscopic examination of the corneal scraping sample, and associated cellular reaction visualized on the cytology (Walsh et al. 2018; de Hoog et al. 2019). These diagnostic tests were selected based on the services offered by the closest laboratory since scraping is a very labile sample and it needs to be processed within four hours (Samanta 2015; Walsh et al. 2018; de Hoog et al. 2019) and also because those exams give important information to confirm the suspected cause.

The key to a successful outcome in keratomycosis cases is an early diagnosis and an aggressive medical treatment for fungi, iridocyclitis, and collagenolysis, with or without surgery. Topical antifungals used to treat this disease include $1 \%$ miconazole, $5 \%$ natamycin, $0.2 \%$ fluconazole, $1 \%$ voriconazole, $1 \%$ ketoconazole, $1 \%$ itraconazole, $0.2 \%$ terbinafine, $0.75-0.5 \%$ amphotericin $\mathrm{B}, 1 \%$ flucytosine, $1 \%$ silver sulfadiazine, and $0.1-5 \%$ diluted povidone iodine. Their effects can vary depending on the geographic region. Most of the times, therapeutic plans are made empirically since antifungal susceptibility testing takes time or cannot be conducted because of the lack of antifungal drugs and the disease progresses rapidly (Galera \& Brooks 2012; Voelter-Ratson et al. 2013; Wada et al. 2013; Utter 2015; Ledbetter et al. 2017).

In the present case, topical miconazole $1 \%$ was used because, up to now, there is no veterinary or human antifungal eye collyrium registered in Costa Rica, and that was the only option available at the compounding pharmacy at the time. Surgery was also suggested but was not performed as per the owner's decision. Topical miconazole $1 \% \mathrm{q} 2 \mathrm{~h}$-q6h has been used as a single or compound therapy (with surgery, autologous serum, and/or Atropine) in several cases and has shown fair results as a treatment for Aspergillus spp. In relation to keratomycosis in horses, the prognosis depended mostly on the previous medications and an early diagnosis (Utter et al. 2010; Wada et al. 2011; Brooks et al. 2013; Voelter-Ratson et al. 2013). 
In a ten-year retrospective study including 66 keratomycosis cases caused by Aspergillus and Fusarium, researchers demonstrated that the case outcomes were not related to the involved fungi, hence there were no significant differences between both genera. The majority of the keratomycosis infections in horses were resolved with eye sparing surgery (46-51\%), followed by medical treatment (32-42\%), and finally by enucleation (12-17\%). Nevertheless, previous antifungal therapy may lead horses to require surgery ( $85 \%$ of the cases), highlighting the importance of selecting the antimycotic until fungal etiology has been confirmed (Sherman et al. 2017).

Antifungal resistance is a concerning threat to fighting mycotic diseases such as the one discussed here. New drugs such as luliconazole (an imidazole used to treat keratomycosis in humans) have become a potential treatment for this disease caused by resistant Aspergillus or Fusarium species in horses, by exhibiting the lowest MICs (Minimum Inhibitory Concentrations) in antifungal susceptibility tests (Roberts et al. 2020). However, its availability and price are restrictive to developing nations, highlighting the importance of implementing the proper treatment in the early stages of the disease.

\section{Conclusion}

To prevent rejection of unaffordable procedures affecting the animal welfare, steroids must be used with caution, or preferably avoided, on horses since they can promote the growth of resident or transitory fungus and/or bacteria resistant to prophylactic medication. If possible, a cytology, direct microscopic examination, and fungal culture are imperative before implementing an antifungal treatment or when superficial corneal lesions and clinical signs do not improve after a few days of empirical treatment.

\section{Acknowledgments}

We would like to express our thanks to Javier Coen for conducting the cytology evaluation and Jordan Aguirres for searching some of the references.

\section{Conflict of interests}

The authors declare no conflict of interests.

\section{References}

Barnett, K.C., Crispin, S.M., Lavach, J.D. \& Matthews, A.G. (eds.). 2004. Equine Ophthalmology: An Atlas and Text, $2^{\text {nd }}$ Edition. Saunders Elsevier, Oxford. p. 107-147.

Brooks, D.E., Plummer, C.E., Mangan, B.G. \& Ben-Shlomo, G. 2013. Equine subepithelial keratomycosis. Vet. Ophthalmol. 16(2): 93-96. doi: 10.1111/j.1463-5224.2012.01031.x

Cafarchia, C., Figueredo, L.A. \& Otranto, D. 2013. Fungal diseases of horses. Vet. Microbiol. 167(1-2): 215-234. doi: 10.1016/j.vetmic.2013.01.015 
Calderón-Hernández, A. \& Urbina-Villalobos, A. 2018. Veterinary mycosis in a tropical country. 20th Congress of the International Society for Human and Animal Mycology. Amsterdam, The Netherlands. Abstract, Med. Mycol. 56: S1-S159. doi: 10.1093/mmy/myy036

Clode, A.B. 2011. Diseases and surgery of the cornea. In: Gilger, BC (ed.). Equine Ophthalmology, $2^{\text {nd }}$ Edition. Elsevier Saunders, Missouri. p. 181-266.

De Hoog, G.S., Guarro, J., Gené, J., Ahmed, S., Al-Hatmi, A.M.S, Figueras, M.J. \& Vitale, R.G. 2019. Atlas of Clinical Fungi, $3^{\text {rd }}$ e-edition. Utrecht/Reus.

Galán, A., Martín-Suárez, E.M., Gallardo, J.M. \& Molleda, J.M. 2009. Clinical findings and progression of 10 cases of equine ulcerative keratomycosis (2004-2007). Equine Vet. Educ. 21(5): 236-242. doi: $\underline{10.2746 / 095777309 X 400289}$

Galera, P.D. \& Brooks, D.E. 2012. Optimal management of equine keratomycosis. Vet. Med. (Auckl). 3: 7-17. doi: $\underline{10.2147 / V M R R . S 25013}$

Gilger, B.C. 2013. Equine Ophthalmology. In: Gelatt, K.N. (ed.). Veterinary Ophthalmology, $5^{\text {th }}$ Edition. John Wiley \& Sons, Iowa. p. 1560-1609.

Houbraken, J., Kocsubé, S., Visagie, C.M., Yilmaz, N., Wang, X.C, Meijer, M., Kraak, B., Hubka, V., Samson, R.A. \& Frisvad, J.C. 2020. Classification of Aspergillus, Penicillium, Talaromyces and related genera (Eurotiales): An overview of families, genera, subgenera, sections, series, and species. Stud. Mycol. 95: 5-169. doi: 10.1016/j.simyco.2020.05.002

Khosravi, A.R., Nikaein, D., Sharifzadeh, A. \& Gharagozlou, F. 2014. Ocular fungal flora from healthy horses in Iran. J. Mycol. Med. 24(1): 29-33. doi: 10.1016/j.mycmed.2013.10.006

Ledbetter, E.C. 2017. Antifungal therapy in equine ocular mycotic infections. Vet. Clin. N. Am. Equine. 33(3): 583-605. doi: 10.1016/j.cveq.2017.08.001

Ledbetter, E.C., Irby, N.L. \& Teixeira, L.B.C. 2018. In vivo confocal microscopy characteristics of equine epithelial and subepithelial nonulcerative keratomycosis. Vet. Ophthalmol. 22(2):168-172. doi: $\underline{10.1111 / \text { vop. } 12576}$

Maggs, D.J. 2008. Cornea and sclera. In: Maggs, D.J., Miller P.E. \& Ofri, R. (eds.). Slatter's Fundamentals of Veterinary Ophthalmology, $4^{\text {th }}$ Edition. Saunders-Elsevier, Missouri. p. 175-202.

Roberts, D., Cotter, H.V.T., Cubeta, M. \& Gilger, B.C. 2020. In vitro susceptibility of Aspergillus and Fusarium associated with equine keratitis to new antifungal drugs. Vet. Ophthalmol. 23(5): 918922. doi: $10.1111 /$ vop.12774

Samanta, I. 2015. Veterinary Mycology. Springer India, New Dehli. p. 41, 155.

Samson, R.A., Houbraken, J., Thrane, U., Frisvad, J.C. \& Andersen, D. 2019. Food and Indoor Fungi, $2^{\text {nd }}$ Edition. Westerdijk Fungal Biodiversity Institute, Utrecht, The Netherlands. p. 39-41.

Sansom, J., Featherstone, H. \& Barnett, K.C. 2005. Keratomycosis in six horses in the United Kingdom. Vet. Rec. 156(1): 13. doi: $10.1136 / v r .156 .1 .13$ 
Sherman, A.B., Clode, A.B. \& Gilger, B.C. 2017. Impact of fungal species cultured on outcome in horses with fungal keratitis. Vet. Ophthalmol. 20(2): 140-146. doi: 10.1111/vop.12381

Utter, M.E., Wotman, K. L., Armour, M. \& Bagel, J. 2010. Clinical findings and outcomes of ulcerative keratomycosis in 30 horses in the mid-Atlantic United State (2006-2007). Equine Vet. Educ. 22(1) 31-39. doi: $\underline{10.2746 / 095777309 X 478}$

Utter, M.E. \& Brooks, D.E. 2011. Glaucoma. In: Gilger BC (ed.). Equine Ophthalmology, $2^{\text {nd }}$ Edition. Elsevier Saunders, Missouri. p. 350-366.

Utter, M.E. 2015. Fungal keratitis. In: Sprayberry, K.A. \& Robbinson, N.E. (eds.). Robbinson's current therapy in equine medicine, $7^{\text {th }}$ Edition. Elsevier, Missouri. p. 611-613.

Voelter-Ratson, K., Pot, S.A., Florin, M. \& Spiess, B.M. 2013. Equine keratomycosis in Switzerland: A retrospective evaluation of 35 horses (January 2000-August 2011). Equine Vet. J. 45(5): 608-612. doi: $10.1111 /$ evj.12042

Wada, S., Ode, H., Hobo, S., Niwa, H., Katayama, Y. \& Takatori, K. 2011. Mortierella wolfii keratomycosis in a horse. Vet. Ophthalmol. 14(4): 267-270. doi: 10.1111/j.1463-5224.2011.00891.X

Wada, S., Hobo, S., Ode, H., Niwa, H. \& Moriyama, H. 2013. Equine keratomycosis in Japan. Vet. Ophthalmol. 16(1): 1-9. doi: 10.1111/j.1463-5224.2012.01004.x

Walsh, T.J., Hayden, R.T. \& Larone, D.H. 2018. Larone's medically important fungi. A guide to identification, $6^{\text {th }}$ Edition. ASM Press, Washington, D.C. p. 44-45, 293-308, 365. 